\title{
IN THE SHADOW OF THE PALM: Dispersed Ontologies among Marind, West Papua
}

\author{
SOPHIE CHAO \\ Macquarie University \\ (iD) http:// orcid.org/0000-0002-5434-9238
}

Rosalina, ${ }^{1}$ a young Marind woman from Khalaoyam village in Merauke (West Papua), is crouched, pale and tired, at the foot of the old mango tree. It is the third night running she has been eaten by oil palm. But last night, she died. In her telling:

It was pitch black. I was on a plantation with my family. We were on our knees, in a big circle, surrounded by oil palm [Elaeis guineensis Jacquin, in Western scientific taxonomy, or sawit in Indonesian]. ${ }^{2}$ Our heads were bent, our hands tied behind our backs, and we were barefoot. I could feel my father was beside me, even without looking at him. The others I did not know. Some of them had bags over their heads, tied around their necks with rope. Everyone was completely silent. Silent, silent, silent.

Nothing happened for a very long time. It was like time had stopped. Time had been eaten by the oil palm. Then I saw that some of the sawit trees surrounding us were not oil palm trees at all, but soldiers. You see, sawit is like the military: patches of black and green. It kills people. It is powerful. It is Indonesian, not Papuan. It eats us. Sawit's spines, sharp like the blades of bayonets. Its fruit, hard and round, like bullets. Red, like blood. Then, a shot rang through the darkness - loud and clear. Pang! My 
father collapsed beside me. Was it sawit that killed him? Then another shot. Pang! The person beside him fell to the ground, without any sound. Was it sawit? I was the last to be shot. I wonder if it was the military men that shot us, or sawit. I wonder if there is any difference. Yes, I must have died last night.

Nightmares of being "eaten by the oil palm," or even shot by it, haunt many indigenous Marind like Rosalina in the Upper Bian region of Merauke, where large-scale monocrop expansion is underway. Agribusiness plantations are being promoted by the government of Indonesia - the world's top palm oil produceras part of the controversial Merauke Integrated Food and Energy Estate (MIFEE), a megaproject geared toward food and fuel production for domestic and international markets (Awas MIFEE 2012). Between one and two million hectares of forest and swamp land will be converted to privatized concessions under the scheme, primarily for oil palm cultivation.

Recurring motifs in dreams of being "eaten by the oil palm" include getting lost in the plantations, violent or sudden death, solitude, and hunger. Dreamers become spatially disoriented and can no longer sense the passing of time. Spirits and the deceased appear alongside bulldozers, the military, and oil palm itself. Human bodies are disfigured as oil palm fruit drupes proliferate subcutaneously like cancerous tumors. Razor-edged palm thorns incubate between sinew and muscle, perforating the skin like arrows shot from deep inside the dreamer's entrails. For women, being "eaten by the oil palm" takes the form of tortured birthings of monstrous oil palm children, both alive and stillborn. These dysphoric nocturnal experiences are one of many acts of violence that Marind of Khalaoyam village, where I conducted my fieldwork, attribute to oil palm, an agentive plantperson of radically destructive inclinations.

In this article, I explore the ontological implications of oil palm's arrival among Khalaoyam residents in light of their preexisting relations with plants and animals, as well as the broader sociopolitical context of West Papua. As a literal and figurative neophyte (from neos, "new" and phuton, "plant" in Greek), oil palm threatens the multispecies cosmology of the forest because it is unwilling to participate in what Isabelle Stengers $(2010,35)$ calls "reciprocal capture," or processes of identity construction where each agent has an interest in seeing the other maintain its existence. Instead, oil palm's self-interested and relentless proliferation subverts morally valued interspecies relations of interessement, Michel Callon's $(1986,17)$ term for the processual "locking" of roles to different entities 
that are implicated in and sustain each other's identities (see also Marder 2013, 131-38; Kirksey 2015, 196-203).

The extension of an agentive self to oil palm aligns with Marind conceptualizations of personhood as a multispecies rather than specifically human trait. Persons, including plants and animals with whom Marind share common descent, are endowed with sentient minds that are expressed through their actions or behavior-for instance, the way they move, reproduce, grow, and sustain themselves. These persons also come into existence through their corporeal relations to other species, notably through the exchange and contact of bodily flesh and fluids including blood, water, skin, and sap. Such interspecies commonalities are a prevalent understanding of many indigenous groups in which social networks encompass other-than-human actors. In Melanesia and Amazonia, for instance, plants may be personified as kin and surrogate children, or classified as male or female. ${ }^{3}$ The sexualization of plants is often associated with procreation and gendered divisions of labor, as well as stages of vegetal growth correlated with the human life cycle and social reproduction. ${ }^{4}$ While native plants feature prominently in these accounts, less attention has been paid to introduced (or invasive) species, such as oil palm in the Upper Bian. Such plants may not be afforded the same moral attributes as those with a well-established status within local cosmologies. Furthermore, ethnographic material on interspecies relations has tended to focus primarily on the agency of the humans involved, rather than the phenomenological lifeworld of their other-than-human counterparts (see Schneider 2013). For instance, plants have often been explored primarily in terms of their function and symbolism as foodstuffs within human systems of exchange and resource use (e.g., Fox 1977; Kahn 1986; Eves 1998).

Recent years have seen renewed attention to vegetal organisms as agentive persons and things, or what Lewis Daly and colleagues (Daly et al. 2016) describe as "botanical ontologies." This article contributes to the "plant turn" (Sheridan 2016, 39) by drawing from the methods and concerns of multispecies ethnography, an emergent interdisciplinary current that explores the agentive lifeworlds of animals, plants, fungi, and microbes in natureculture borderlands (Kirksey and Helmreich 2010). Much of this literature has sought to displace notions of human exceptionalism and to rehabilitate disaffected or exploited species by calling for "passionate immersion" (Tsing 2011, 19) in the experiential realms of diverse organisms that humans "become-with" (Wright 2014).

A growing body of literature exploring plant-human encounters is taking root in multispecies approaches (e.g., Hustak and Myers 2012; Schrader 2012; 
Berrigan 2014; Myers 2015; Tsing 2015; Hartigan 2017). Yet discussions of the more-than-human have largely centered on animal-focused studies, often carried out in Western, urban, or technoscientific settings. For instance, research on "lively capital" (Sunder Rajan 2012) within mass-production circuits has focused primarily on animal commodification (e.g., Collard 2014; Lien 2015; Beldo 2017; Blanchette 2017) rather than cash-crop production and its perhaps less obvious ethical implications for the plants themselves. ${ }^{5}$ The exclusion of plants from moral purview, which James Wandersee and Elisabeth Schussler (2001) describe as "plant blindness," likely stems from the widespread perception in Western cultures of vegetal life forms as sessile, unconscious, incapable of feeling pain, and thereby lacking the vitality that characterizes humans and animals (see also Hall 2011; Marder 2013).

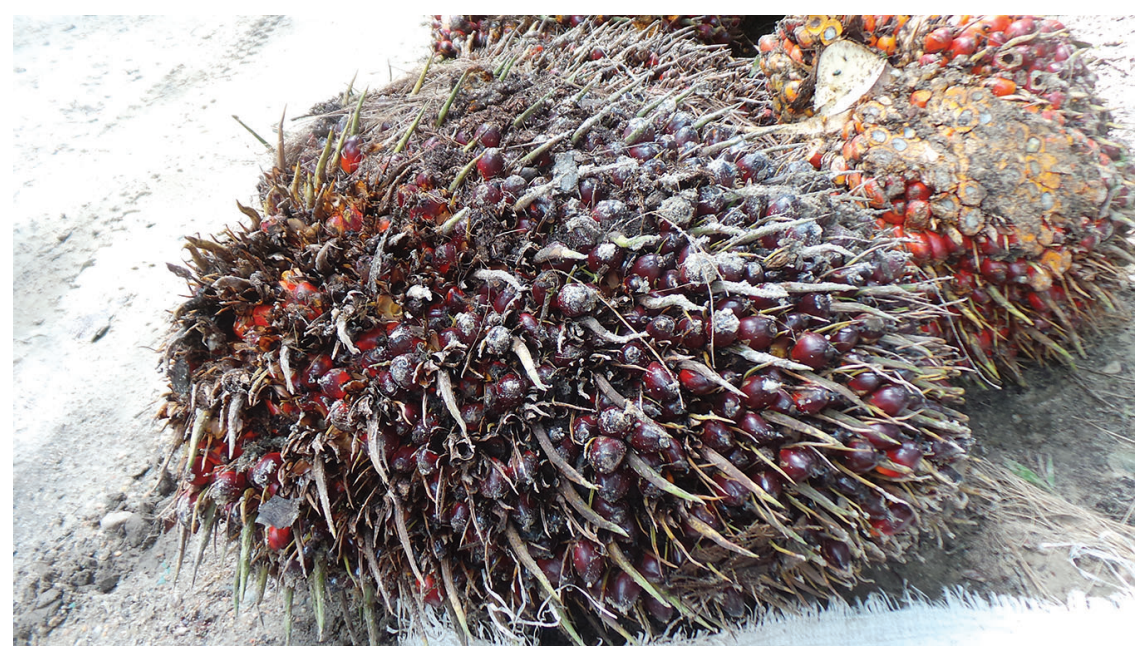

Figure 1. A mature oil palm fresh fruit bunch. Photo by Sophie Chao.

This article provides a counterpoint to the predominantly Western- and zoo-centric focus of multispecies ethnography by exploring the perspectives of a group of indigenous Papuans in an "out-of-the-way place" (Tsing 1993), whose loving relations with kindred forest organisms are jeopardized by the advent of a profoundly immoral and invasive plant-person. While scholars in the environmental humanities speak of the need to cultivate love for other species, many among my interlocutors are grappling with a vegetal being that is violently unloving. Furthermore, plant-human relations in Merauke problematize the multispecies effort to decenter the human and encourage the flourishing of other 
beings. Such an approach brings us into alliance with a plant that is doing harm to people who are themselves historical victims of the kind of "racializing assemblages" (Weheliye 2014) that render them killable or subjectable to dispossession (see also Kirksey 2017, 195-96). Marinds' heterogeneous perspectives on oil palm thus invite us to rethink violence in multispecies terms. The exceptionally destructive attributes of oil palm expose the unloving nature of some other-thanhuman organisms and the situatedness of who is deemed loving or unloving. These affectively charged categories cannot be reduced to human and other-than-human dichotomies. Nor can they assume that the perpetrators of violence are always necessarily human.

\section{ALWAYS HUNGRY, SAWIT HAS NO FRIENDS OR FAMILY}

Khalaoyam village is home to some two hundred Marind households who derive their subsistence primarily from hunting, gathering, and fishing. Within Marind cosmology, the forest constitutes an "ecology of selves" (Kohn 2013, 16) in which selfhood is extended to plants and animals. Each clan (Marind: bawan) is related to grandparent (amai) or sibling (namek) species (see van Baal 1966), with whom it shares bodily wetness (dubadub) and skin (igid), the primary markers of relatedness in Marind conceptions of personhood. Humans and amai sustain their mutual existence through everyday practices of reciprocal care. Amai grow to support humans by providing them with food and other resources. In return, Marind exercise respect and restraint as they interact with amai in the forest, recall their stories, hunt, gather, and consume them.

As they walk across the landscape, Marind attune to the presence and activities of amai whose diverse lifeways and relations endow the forest with temporal, moral, and affective texture. People trace kinship connections with each other through the sites at which their respective amai settled, rested, hunted, or fought. Sago palms, in particular, are celebrated as symbols and sources of fertility and nourishment. Their propagation defines customary land boundaries and natural resource use within the landscape, producing rooted identities among those who manage, exchange, and consume their starch (see also Ellen 2006; Stasch 2009, 25-30). As they sweat, work, and eat together among sago stands, Marind affirm their social relations to each other and derive evident pleasure from observing the growth of sago and its symbionts, which, together with the rivers and forest soil, endow the grove with life-generating wetness. Forests and groves thus emerge from the dynamic relations of humans and their plant and animal kin, 
who participate in each other's existences as members of a shared community of life, or what Marshall Sahlins $(2011,2)$ describes as a "mutuality of being."

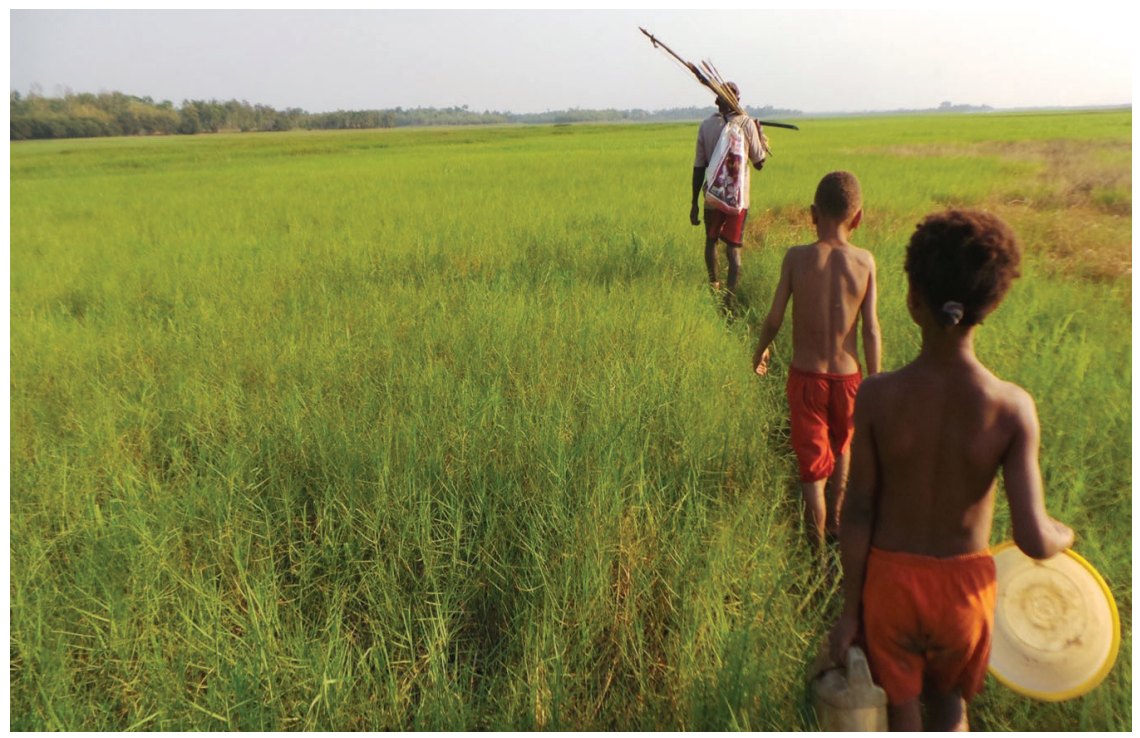

Figure 2. A Marind family walking to the sago grove. Photo by Sophie Chao.

In contrast, sawit's rapacious appetite for land and water is characterized by nonreciprocity and insatiability. Forest organisms are obliterated as vast swaths of forest are burned or felled and replaced with 10,000- to 100,000-hectare concessions dominated by a single plant. Sawit gnaws away at the soil, leading to erosion, abrasion, and subsequent siltation (Obidzinski et al. 2012). When a prolonged drought afflicted Merauke in 2015 and 2016, young and old alike affirmed that sawit drinking up the wetness of the rivers caused this unprecedented event. As he described the bulldozers clearing the forest to make way for irrigation channels, Antonius, a man in his twenties, noted how the redirection of the Bian River left humans, mangroves, and animals parched. Picking up a clump of dry earth in a razed sago grove, he compared sawit to suanggi, or perpetrators of black magic. Just like oil palm depletes the wetness of the forest, suanggi attack their victims by sapping their fluids until their bodies dry out, leaving only a tottering husk of skin prior to their imminent collapse and death.

Sawit also pollutes watercourses with the effluents from the mills where it is processed. After failing to catch fish to feed her three children, Selly, a middleaged primary school teacher, pointed to the murky surface of the Bian River and 
told me how endemic fish and amphibians were "losing their way" in their murky milieus. Underwater, riverine life forms become "drunk on poison" and suffer from eutrophication as oxygen availability is redirected from aquatic biodiversity to rapidly growing algae. Meanwhile on land, the skin of terrestrial organisms rots away from irritations caused by pesticides that seep into the water they drink and bathe in.

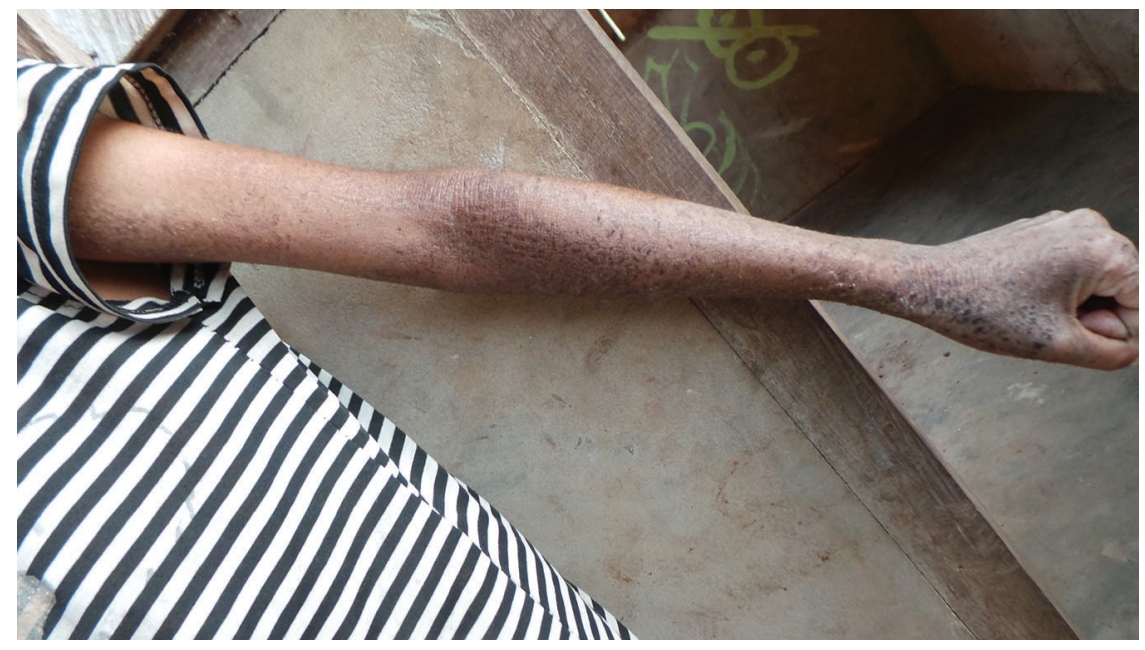

Figure 3. Skin infections are symptomatic of the "drying out" of place caused by oil palm expansion. Photo by Sophie Chao.

Sawit's insatiable greed is accompanied by a solitary mode of existence. As we drove past a 20,000-hectare concession, Yulianus, Antonius's brother, contrasted the uniform landscape to the diverse flora and fauna of the forest, concluding that sawit "has few friends" and "likes to be alone." Indeed, few life forms are able to make a "companion species" (Haraway 2008) of sawit in agribusiness plantations, which are characterized by low canopies, sparse undergrowth, unstable microclimates, high temperatures, and frequent chemical spraying (Fitzherbert et al. 2008). The conversion of natural forests to plantations also increases habitat fragmentation and biodiversity loss, and forms impervious barriers to species migration (Meijaard and Douglas 2013).

Yet at the same time as many Khalaoyam community members struggle to curb the expansion of oil palm, they have learned from their urban kin and NGO workers that they themselves routinely use and consume foods and goods that contain palm oil_ - instant noodles, ketchup, shampoo, and soap, for instance. As 
we queued at the local kiosk to purchase biscuits for the school fair, Maria Mahuze, a primary school teacher, acknowledged: "We hate sawit, but we eat it every day. We have no choice." This is compounded by the fact that palm oil is difficult to identify as an ingredient because it is usually labeled as generic vegetable oil, or one of more than two hundred different organic compounds. ${ }^{6}$ Crumpling the biscuit packet with frustration, Maria commented: "Sawit is everywhere, but it keeps its secrets well.”

\section{DOMESTICATED AND FOREIGN}

Perpetua, a midwife in her late fifties with whom I often processed sago in the forest, frequently described oil palm in contrast to bamboo, the amai of her clan. The main difference, Perpetua noted, was that bamboo was native and wild, whereas "sawit is domesticated and foreign - it grows here, but its roots are elsewhere." Underlying this statement are two sets of distinctions central to Marind multispecies personhood-making - the wild (Indonesian: liar) and the domesticated (pelihara), and the native (asli) and nonnative (pendatang).

To be native means to retain a certain degree of wildness and, through that, of freedom. Various forms of restrained care ensure a balance maintained between respecting individuals' autonomy and establishing relations with them. For instance, Marind are reluctant to engage in horticulture because it involves overly manipulating plants' growth and taking away their freedom. They do not rear animals for the same reason. ${ }^{7}$ Instead, Marind engage in indirect acts of "minimal manipulation" (Groube 1989, 300) that make the environment more conducive to animal and plant well-being. For instance, they support sago growth by thinning the canopy, removing epiphytes from the base of the tree and burning vegetation that inhibits the growth of suckers. Similar principles shape interactions among Marind themselves. People create relations through collective acts of exchange, but they also actively avoid imposing themselves on others in ways that violate their autonomy of thought and action.

Otherness as the focus of social relations (see Stasch 2009) thus operates within and across species lines among Marind. Each organism is as much the product of multiple human acts of restrained care as it is the product of the organism's own self-willed modes of growth and relations. Respect for the capacity of beings to live autonomously yet in relation to each other within multispecies social and ecological networks (Collard 2014, 154) enables loving relations between humans and their forest kin. 
In contrast, agriculture, and more specifically monoculture, entails the radical reorganization and simplification of the environment toward human ends, at the expense of natural diversity (J. Scott 1998, 2; Tsing 2011, 19; Marder 2013, $55)$. Indeed, the monocrop plantation model is favored because the product harvested - being uniform in size, dimensions, and yield - fulfills the criteria of a homogeneous market commodity, thereby reducing the risk of revenue fluctuation (J. Scott 1998, 18). Agribusiness cultivation disrupts the ethos of restrained care that enables loving interspecies relations and instead embodies an extreme form of domestication or violent care - the "flip side" (Tsing 2005, 30) of valued wildness. The uncontrolled proliferation of sawit results in a sort of ontological topheavy fraction in which oil palm unilaterally imposes its presence on others, thus casting the reciprocal relations of Marind and their amai kin into lethal cosmological imbalance.

Many of my interlocutors contextualize the ontological predation of sawit within the broader sociopolitical history of West Papua, where continued internal colonialism goes hand in hand with egregious human rights abuses, community impoverishment, rampant exploitation of natural resources, cultural assimilation, and heightened military presence (see Timmer 2007). In particular, the proliferation of sawit bears ominous resonances with the once state-endorsed and now spontaneous influx of (primarily Muslim) non-Papuan settlers in West Papua, further boosted by the labor opportunities presented by the MIFEE project (Farhadian 2005, 63). Just as oil palm takes over customary forests to the detriment of Marind and their other-than-human kin, so too Marind are increasingly outnumbered by non-Papuan transmigrants, who in 2017, comprised some 68 percent of Merauke's population (Elmslie 2017).

Many Khalaoyam villagers also associate sawit with the National Indonesian Army, as we saw in Rosalina's dream. As with military garrisons and training grounds, of which there are many in the national border zone of Merauke, plantations extend across vast areas of land and remain off-limits to nonpersonnel, with trespass heavily sanctioned. Company guards and company-hired military units strictly guard the entrances. Rows of equidistant oil palm trees crisscross the plantations much like a regiment of obedient, disciplined soldiers, identical to each other in appearance and size. Young Marind men sometimes compared the temporality of sawit's homogeneous, controlled growth and regular harvesting to the appearance and movements of marching soldiers. They also noted that terms used in the context of military spatial organization are also employed by 
oil palm companies to describe the breakdown of plantations into divisions, districts, building complexes, blocks, and echelons.

In historical terms, the arrival of sawit is the latest in a long series of confrontations between Marind and unloving foreign others. Dutch rule and the influence of missionaries led to forced sedenterization, the imposed cultivation of nonnative crops, and the abolishment of ritual practices that had once sustained kinship bonds between clans and with amai. While foreign plume-hunters decimated bird of paradise populations in the forest (Swadling 1996, 176-99), viral and bacterial organisms ravaged Marind communities in the form of influenza and lymphogranuloma venereum (van Baal 1966, 24-25). ${ }^{8}$ With the influx of Indonesian officials, settlers, and military forces following the transfer of the administration of West Papua to the Republic of Indonesia in 1963, large-scale landscape conversions continued in the form of rice cultivation, oil palm plantations, and mining and logging concessions (Monbiot 1989; Marr 2011). ${ }^{9}$

In this light, the violence wrought by sawit constitutes the latest emanation of memoria passionis, a term used by West Papuans to denote the collective suffering and oppression they have endured since the region's forceful incorporation into the Indonesian state (Hernawan and van den Broek 1999, 8). Sawit participates in the region's ongoing domination as the state's "biological ally," a term developed by Alfred Crosby $(2003,52)$ to refer to plants and animals that thrived as they traveled alongside human colonizers across geographical realms. As concession boundaries in Merauke continue to multiply, the powers that govern the expansion of this alien and invasive plant remain firmly rooted in the political heart of the country-Jakarta.

\section{WHERE IS ITS FAMILY, WHERE IS ITS HOME?}

Sawit plantations are the latest addition to a network of state and corporate projects that together constitute a topography of terror not unlike the one explored by Chris Ballard (2002) among Amungme near the Freeport copper and gold mine in West Papua. Plantations, along with the other nodes of this pervasive network - roads, military posts, kiosks, and clinics - are pharmakonic in Isabelle Stengers's $(2010,29)$ sense of being uncertain in their effects, alternately poison or remedy. For instance, plantations come with attractive compensation packages, welfare schemes, and employment opportunities for indigenous landowners. Yet in fact, oil palm companies do not implement most of these (largely verbal) agreements due to lack of funds and goodwill, or else the results fall short of communities' expectations. Corporations promote agribusiness as a means to 
integrate rural communities into a modern and civilized lifestyle. Instead, geometric concessions of strictly guarded boundaries disconnect humans from their kindred species and thwart the multispecies movements through which places and persons accrue meaning.

In Highland Papua New Guinea, Porgerans affirm "the land is ending" because of gold mining and its morally laden cosmological and social impact (Jacka 2015, 240). A similar expression exists among Khalaoyam community members who affirm that with the advent of sawit, time is "ending" or "drying out." Many of my interlocutors point to the disappearance of forest organisms as evidence of this radical temporal rupture. For instance, as we walked through the rubble of a razed sacred forest, Marcus, an elder in his seventies known for his skill in imitating animal sounds, noted how the call of birds marking the break of dawn and the fall of night had become rare. Hunting, fishing, and gathering had become difficult because the times of fruit maturation, bird and animal migration, and fish and amphibian reproduction had halted indefinitely. By imposing a mono-time of homogeneous growth on forest organisms, sawit obstructs their different temporalities of life and the very possibility of their continued existence and relations. Its proliferation obliterates the spatially experienced past that, in turn, forestalls the possibility of a meaningful present and thwarts the shared futures of the forest's dwindling communities of life.

Sawit's ontology constitutes a doubling up of sorts. On the one hand, it is almost oversaturated with meanings that relate to its destructive effects on space, time, and the morally valued reciprocity of multispecies relatings in the forest. On the other hand, it is characterized by a deep-seated ambiguity resulting from a lack of knowledge on the part of Khalaoyam's inhabitants about what sawit wants, where it comes from, and how they might establish relations with it. Ruben, a young man who had once been involved in a rice-cultivation project near Merauke city, noted that sawit itself is in its early years of infancy, having only been planted in the last two or three years. Little is known of its modes of growth because, as Ruben said, "sawit is still a child." The plant's ambivalence is heightened by the absence of encounter with sawit's human counterparts by Khalaoyam villagers. The nature of oil palm production means that plantation workers are few, seasonal, and spread out over vast expanses of land. Higher-level company staff are housed in the plantation living quarters, mills, and offices, restricted in their access to company personnel.

The ambiguity of sawit's ontology gave rise to widespread curiosity among my interlocutors. Many looked to church organizations, NGOs, and myself for 


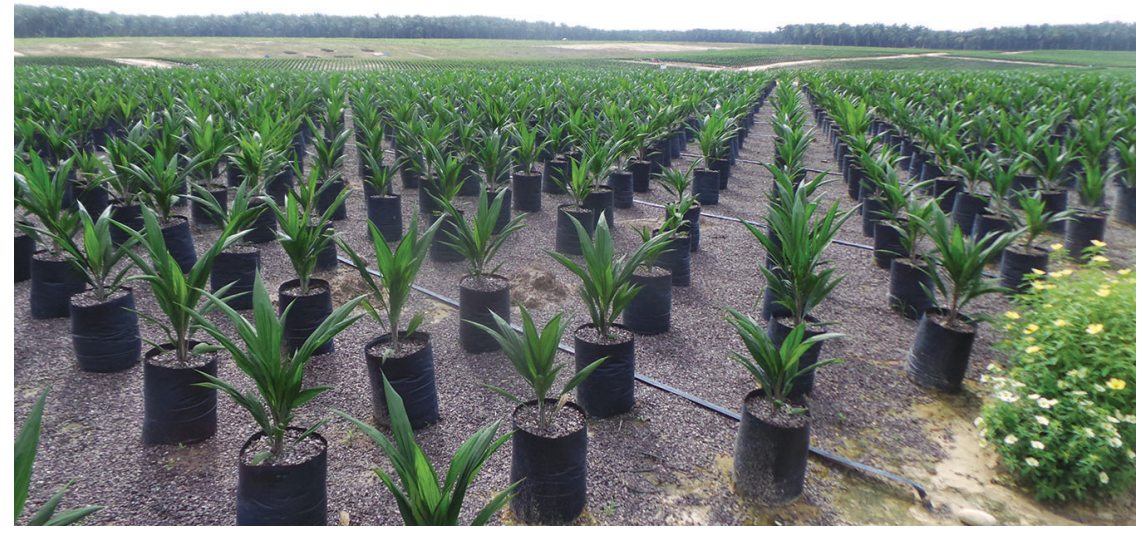

Figure 4. In most of Merauke, oil palm plantations are still in their infancy. Photo by Sophie Chao.

information about the processes, labors, actors, and institutions involved in palm oil production. They found themselves intrigued by how oil palm transforms from plant to product as it travels from the nursery to the plantation, and beyond that to the mill, refinery, and to supermarket shelves. Younger Marind often asked me about the countries and communities that would eventually purchase the palm oil grown on their customary lands. When contrasting the destructive effects of sawit with the reciprocal relations of care characterizing their relations to forest organisms, my friends pondered whether sawit has "ever known the wild" or "what it is to be free," in other places, at other times, and with other companions. As she watched truckloads of newly sprouted seedlings rumble down the road from Merauke city, Elena Balagaize, an old widow originally from the upstream village of Mirav, mused: "Sawit, too, has a family and a home, somewhere far away. Where is its family, where is its land? Does it not miss them? Does it not want to return to them?"

The opacity of sawit generates sentiments of fear, anger, and dislike among many Khalaoyam community members who affirm that sawit thrives off its condition of domestication without qualms about the annihilation of other species' worlds. Yet oil palm also comes with the potential of progress and development. Landowners who endorse the plantation sector take pride in contributing to regional economic development and national food security, as well as in helping feed the biofuel-hungry nations of Europe and the United States. Oil palm may 
be destructive, but it also offers the possibility of new connections to faraway places, peoples, and profit. Otherness coalesces in the body of sawit as an ambivalent object of longing and loathing (see Rutherford 2003).

Finally, a small number of villagers feel sorry for sawit because it has been forcefully uprooted from its native home and overwhelmingly subjected to human control. For instance, as we sat in the community hall watching drone footage that I had captured of a nearby oil palm plantation, Yulianus wondered if sawit ever felt "lonely" in the uniformity of the monocrop landscape. His comment reminded his sister, Evelina, of a recent consultation organized by the plantation operators, during which she had learned that oil palm seeds were genetically modified by humans and made to grow in plastic bags and industrial nurseries. More than twenty-five different kinds of pesticides, she told us, were used to spur their maturation and those that failed to perform were culled en masse. Evelina pitied these kinless seeds that she called "orphans" because their growth and development (and eventually, death) did not occur freely but rather under total human control. Similarly, Mariana, a young girl who had recently given birth to her first child, expressed sorrow over the fate of oil palm fruit - or "sawit children" (Indonesian: anak sawit) - that she had seen ripped from their parents during harvesting and unceremoniously flung into overloaded trucks "like dead bodies."

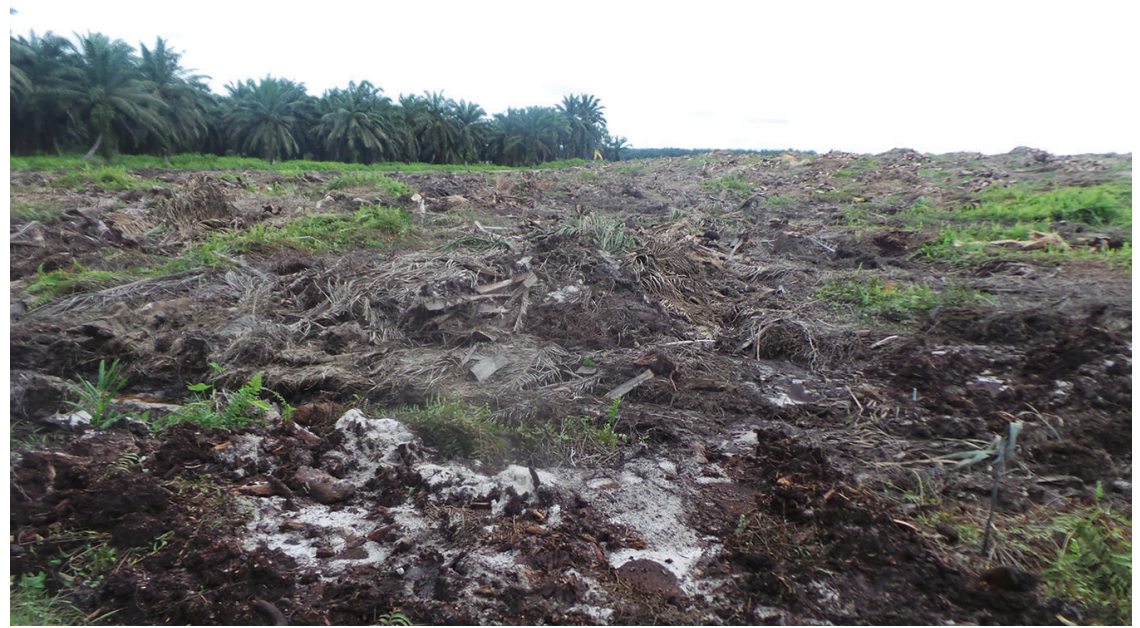

Figure 5. Forest cleared to make way for an oil palm plantation. Photo by Sophie Chao.

Sawit does violence to the inhabitants of the Upper Bian because it eats the land, rivers, and forest of Marind and their other-than-human forest kin. Yet the 
plant itself is also violently manipulated and exploited, burned up as calories and combustibles by bodies and vehicles far removed from its source. Consumed at the pyre of modernity, sawit is at once victim and driver of what Michael Marder (2014) aptly calls the "pyropolitics" of the contemporary era. And while real fires, set by oil palm companies for land-clearing purposes, ravage the landscapes of the Upper Bian, sawit also fires the imagination of Khalaoyam inhabitants, who express a deep sense of curiosity as much as animosity in their speculations about sawit.

\section{TOSSING AND TURNING WITH ONTOLOGY}

Ethnographies of agribusiness have attended primarily to the experiences of peasant groups involved in the plantation sector as workers or smallholders (e.g., McCarthy 2010; Dove 2011; Li 2014; Tammisto 2018). In the Upper Bian, by contrast, villagers suffer oil palm's relentless expansion even as they remain excluded from its sites and circuits of production. More importantly, the adverse impacts of agribusiness are not attributed to the humans and institutions driving oil palm expansion, but to oil palm itself. Giving center stage to plants in a world where vegetal beings are violent and humans their victims reveals that human exceptionalism may constitute just one of many possible kinds of destructive exceptionalism, one in which other-than-human life forms might figure not as "unloved others" (Rose and van Dooren 2011) but rather as unloving others.

In positioning themselves as one kind of self among a plethora of agentive life forms, Marind embody a posthuman ethic that drives theories of ontological anthropology and multispecies ethnography. The insights revealed by plant-human relations of the Upper Bian suggest that central ethical tenets of the multispecies approach - respect, response-ability, immersion, and care, for instancecould usefully draw from the cosmologies of indigenous groups like Marind who incorporate other-than-human entities within their social relationships. At the same time, the forces of oil palm as lively capital in Merauke invite greater attention on the part of anthropologists to processes of ontological transformation. In particular, such approaches might attend to how new and not-always-human actants, such as oil palm, not only travel across and disrupt ontologies (Bessire and Bond 2014, 446) but also actively participate in the fashioning of contested and dispersed realities across scale and locale. This approach could be extended to explore the moral position occupied (sometimes literally) by other mass-cultivated or reared and often introduced species - soy, sugarcane, jatropha, and cattle, for instance - within indigenous lifeworlds, and their ontic relations (or 
lack thereof) with native life forms of established cultural significance, human or other.

Ontological analytics and the multispecies turn are closely linked in their drive toward an "anthropology beyond the human" (Kohn 2013), inspired in part by the many non-Western "sentient ecolog[ies]" (Anderson 2000, 116) that extend personhood to all beings with a perspective. Despite their shared intellectual and ethical drive, however, their compatibility in terms of understanding sawit's lifeway proves problematic. On the one hand, the anthropology of ontology suggests that we take the diverse beliefs and discourses on sawit upheld by Khalaoyam community members as possibly real in their own right. On the other hand, an interdisciplinary approach to sawit's lifeworld, as the multispecies turn favors, would likely move away from what might be seen as the anthropomorphization of sawit by Marind. It might reveal all kinds of ecological facets of sawit's lifeway that, first, my interlocutors might not know, and second, that might demonstrate how their truths about sawit diverge from what Western science tells us of oil palm's attributes and effects.

For instance, recent advances in oil palm ecological science demonstrate that oil palm plantations can support communities of flora and fauna that have found ways of living in symbiosis with sawit. ${ }^{10}$ The drought attributed to sawit also results from fluctuations in temperature between the atmosphere and the ocean, otherwise known as the El Niño-Southern Oscillation cycle. If some among my interlocutors pity oil palm for its totalizing subjection to human control, my own research in an oil palm plantation revealed that breeders and geneticists in fact become deeply emotionally invested in the seeds they manipulate (Chao, forthcoming). And as damaging as oil palm is to the people of Khalaoyam, it remains the optimal choice in terms of land-to-yield ratio compared to other vegetal oil competitors - the lesser of two evils, so to speak.

Of course, whether and how perspectives on oil palm differ across actors and sites is something to be discovered rather than assumed. Oil palm's reality does not consist solely in its narrow ecological entanglements but in its placement within a historically specific situation that includes global capitalist trends, regional geopolitics, and national developmental and political projects. In many ways, my informants' multifaceted characterization of oil palm captures elements of this wider reality in ways that a purely secular technoscientific approach would not. One might therefore approach Khalaoyam inhabitants' accounts of oil palm as an elaboration of the scientific worldview, not (just) an alternative to it. At the same time, my interlocutors conceive the plant's reality in highly heterogeneous ways, 
from driver of destruction to victim of human exploitation. Their theories of reality are perpetually in the making and transform in the light of new encounters, experiences, and knowledge.

From a Western secular scientific perspective, oil palm may not be the antisocial creature that many Khalaoyam individuals describe. Yet to refute their worldview on this basis and focus purely on oil palm's generative entanglements is to ignore (perhaps even perpetuate) the violence enacted by oil palm against a people themselves subjected to ongoing political and cultural discrimination. At the same time, to refrain from imparting ways of knowing sawit rooted in alternative ontological frameworks also seems unsatisfactory, as it suggests that ontologies are somehow bounded, that communication across them is impossible, or that doing so in some sense patronizes or corrupts our informants' theories of reality. Indeed, my interlocutors' own curiosity about the lifeworld of sawit beyond Merauke - its origins, kin, and home - suggest they recognize that the unloving impacts they suffer from sawit may obscure loving relations that the plant entertains with other life forms in other places. The moral complexities generated by this recognition can equally act as a fruitful avenue for rethinking discourses and practices surrounding unloving humans.

Whose reality matters (more) under such circumstances? How do we find a balance between the multiple and often contested realities of humans about other-than-humans and the realities of other-than-humans beyond their human context? Weaving together the lifeworlds of different species as situated (and sometimes suffering) beings is a matter of ethics and responsibility. As Donna Haraway $(1997,129)$ notes, choosing which realities to follow and moving transversally across cosmologies always marks an analytical, imaginative, physical, and political choice. Whether a species is loving or unloving, and therefore loved or unloved, comes down to perspective.

Eschewing representationalist approaches to non-Western worldviews, Eduardo Viveiros de Castro $(2011,135)$ notes that taking what people think as expressive of a truth does not necessarily mean believing in that truth, but rather sustaining its possibility. However, the consequences of exhorting openness to alternate realities in the real world (so to speak) of advocacy can prove challenging. For instance, positing sawit as an antisocial person and time-eater-as "true" as this may be- in multistakeholder negotiations with states and oil palm corporations can reinforce entrenched stereotypes of Papuans as primitive and superstitious peoples, in turn enhancing the perceived need for the kind of development that drives projects like MIFEE in the first place. 
Khalaoyam land rights activists themselves are acutely conscious of the politics of ontological disclosure and performance as they struggle for recognition in the face of multinational conglomerates, state agencies, and international financial institutions. Their pursuit of ecological justice entails astute negotiations and collaborations (Kirksey 2012, 1, 5) not only with oil palm but also with the human others who constitute this industrial plant's allies. In these complex plant-human entanglements, how indigenous actors engage in strategic self-representation before powerful and predatory audiences (see Rutherford 2012) profoundly determines the shape of reality itself.

\section{DISPERSED ONTOLOGIES}

Moving away from Cartesian dualisms, ontological anthropologists reject concepts as static, discrete, and universal entities and instead attend to "the web of relations which inhere in things and in which things inhere" (M. Scott 2013a, 863). Plants, in broad terms, are good to think as an embodiment of relational becoming. They demonstrate remarkable phenotypic plasticity in their interactions with environmental surrounds. Plants' existence is also one of perpetual metamorphosis. Growth and senescence occur simultaneously across their leafy limbs and radiating roots. As "sub-organismic processes and supra-organismic ensembles" (Marder 2016, 64-65), vegetal beings incarnate the dividual par excellence (Battaglia 2017, 18-19).

At the same time, the specific plant that is sawit teaches us a less appreciated (but no less politically significant) dimension of relational living/thinking: its limits. Like settlers, the Indonesian state, and the military, oil palm does not belong in Merauke because it fails to participate in the reciprocal exchanges through which places and persons become physically and ideologically consubstantial (Leach 2003; Stasch 2009). Its proliferation erodes the "cosmic economy of sharing" (Bird-David 1992, 30) of the forest and violates the principle of restrained care that enables loving relations across species lines. Instead, oil palm constitutes a vegetal form of "significant otherness" (Haraway 2003) that imposes itself on preexisting multispecies lifeworlds and appropriates the resources necessary to their survival only to sustain its own.

As I demonstrate in this article, investigating plants like oil palm as antagonistic yet ambivalent actants has consequences for anthropological methods and ethics in worlds where opacity proves constitutive of meaningful ontologies (Graeber 2015). Indigenous theories of reality in the Upper Bian are far from singular or static. At once agent and subject of destruction and exploitation, oil palm 
multiplies ontologically across divergent interpretations of the plant's ways and wants. Whose reality matters, how, and to what end complicates the notion of bounded ontologies as these reveal themselves to be "sticky," a term Sara Ahmed (2010, 90) has developed to describe sites of ambivalent affects produced by complex histories of contact between bodies, beings, and objects. I offer the notion of dispersed ontologies to highlight the entanglements through which human and other-than-human realities come into existence, and the limits to which interspecies relationings are possible and mutual in the capitalist ecologies of monocrop plantations.

Dispersed ontologies help characterize the ontological live-liness of interspecies engagements. These engagements are pregnant with the possibility of fusion and fission. For instance, the ontology of the forest is dispersed across Marind and the manifold, agentive other-than-human beings with whom Marind entertain loving relations of care and reciprocity. No single entity, human or other, constitutes the center of this dispersed ontology. Rather, all beings participate equally, if differently, in enlivening each other's existences in morally valued and affectively charged ways. Just as there is no singular Marind reality, so too sawit constitutes a "boundary object" (Star and Griesemer 1989) that accrues meaning as it travels across spatial and conceptual realms, drawing together disparate individuals, communities, and institutions. We too participate in the dispersed ontology of oil palm by consuming its oil, which is present in over half of all packaged goods in the world.

But just as dispersion has no permanent center, so its limits and impossibilities are contingent. "Nondual" worlds_-Michael W. Scott's (2013b) term for ontologies that arise from relations in perpetual flux - may not always be able to fit all exigencies, or to contract or expand their scales to absorb and accommodate all kinds of others, particularly when these others, like sawit in the Upper Bian, do not reciprocate in lively dispersion. The "co-opting of strangers" (Margulis and Sagan 2000, 20) in symbiotic relationship can fail. Dispersed ontologies are more akin to improvisations than choreographies (Cussins 1996), in that "contact zones" (Haraway 2008, 244) are not always successfully or evenly achieved, and those who participate in them are not always expected, invited, or wanted. In this light, distinguishing wanted from unwanted relations, imposed and impossible transformations, is part of recognizing the tipping point of ontological resilience (Jacka $2015,1)$. For many in Khalaoyam, sawit embodies the limit of reciprocal relations across species lines. 
If ontic dispersion characterizes the plant-person relations of the Upper Bian, epistemic dispersion may help us apprehend the reality of sawit in ways that transcend conventional cultural anthropological research techniques (see Hartigan 2014; Myers 2015). As humans, we may never be able to inhabit oil palm's Umwelt, the German biologist Jakob von Uexküll's (1957) term for the perceptual world of other-than-human organisms. However, we may deepen our understanding of its dispersed ontology by means of an epistemic nomadism that draws diverse actors and institutions toward a "non-unitary vision" (Braidotti 2006, 11) of oil palm as plant, part, and product.

Insights into the realities and relations of oil palm and its multisited "social worlds" (Barnes 2016) might weave together history, economics, philosophy, biology, plant science, anthropology, and indigenous cosmologies, much as critical plant studies scholars are now attempting to do. Such approaches engage knowledges, practices, and actors through transformative dialogue in a form of inter disciplinary and inter sited cross-pollination (see Marder 2016). Indigenous conceptualizations of plants as animate beings, for instance, might be brought into conversation with the emergent science of plant intelligence (e.g., Trewavas 2005; Chamovitz 2013). Similarly, indigenous notions of vegetal agency might be explored through the optic of evolutionary niche construction to examine how oil palm shapes and enhances its environment through consequential, if unconscious, modes of environmental engineering. Certainly, navigating the politics of “situated knowledges" (Haraway 1988) is challenging. Yet working transversally across epistemic divides may allow new ways of understanding and relating with oil palm to flourish-other- and wise-ly.

\section{THE TREES THAT WON'T HUG BACK}

My host sister Mina and I were waiting for our flight from Merauke to Jayapura. Mina, who was born and raised in Khalaoyam, was texting family, while I was reading an article arguing fervently that Donald Trump was the best solution to tackling "free spenders, organizers, race baiters, intellectuals, tree huggers, and professional value arbitrators." Mina glanced over and picked up on the word tree, which she had learned a few weeks before. "What is a tree-hugger?" she asked me. I explained that it meant an environmental campaigner, the expression derived from activists literally hugging trees to protest their felling. Mina went silent, then asked: "But what if the trees won't hug you back?"

The ethical and ecological urgency driving much of the multispecies and eco-philosophical literature suggests that while multispecies encounters do not 
guarantee either happy or unhappy endings (Haraway 2008, 15), generally the human party is assumed to be committing violence to its other-than-human companions by failing to exercise respect, curiosity, and care toward them. Yet the call to respect the difference of the other-than-human in a nonhierarchical way proves limited if it fails to recognize that it is not always a human/other-thanhuman dualism that underlies species hierarchies, and that humans are not necessarily the more powerful entities in interspecies relations. In the Upper Bian, it is the person-plant of oil palm that obliterates other species, and a particular group of humans that is struggling to relate to the "unexpected country" (Haraway 2007) of monocrop plantations. In this context, assuming that only humans are capable of violence to other-than-human life forms may constitute yet another instance of human exceptionalism.

If giving voice to marginalized beings on the edge of extinction is never morally unproblematic, to "stay with the trouble" (Haraway 2016) of proliferating other-than-human entities that, as Mina put it, "won't hug back" is perhaps a thornier task. Here, taking love seriously in plant-human relations (see Archambault 2016) also requires taking seriously its affective counterparts - hate, pity, and ambivalence. Some plants commit "acts of love" (Marder 2016, 25), while others commit acts of violence. "Double death" (Rose 2004, 175) in the Upper Bian is the shared fate of all beings eaten by oil palm. In these multispecies entanglements, some humans bear the palm in profit, while others must bear with it.

Multispecies ethnographers have tended to highlight sensorial immersion, phenomenal contact, affective receptivity, and empathetic response-ability as valuable tactics in encountering (and taking seriously) our other-than-human companions. Encounterings (Despret 2004), entanglements (Kohn 2013), fingeryeyes (Hayward 2010), touch (Barad 2012), and immersion (Tsing 2011) are some of the many words used to describe interspecies relationships in the phenomenal sense. For Khalaoyam residents, however, the difficulty of encountering oil palm, combined with the elusiveness of its supply chain and the facelessness of its consumers, are precisely what give rise to its ambivalent ontology.

This suggests that attention needs to be paid to the absence and impossibility of multispecies encounters and relations, as well as the role of the imagination in the making of speculated encounters. To not be able to touch or be touched can also be the source of creative imagination, a form of speculative haptics (i.e., the imagination of what the touch of a possible encounter might entail) rather than haptic speculation (i.e., the imagination triggered by the touch of an actual en- 
counter; Puig de la Bellacasa 2009, 310-11). Distance, loss, and imagined encounters matter just as much - albeit immaterially - in the entanglements of species. Perhaps the anthropology of ontology, with its emphasis on taking reality seriously, needs to make space for a speculative practice of the imagination whose effects stem from what is not there, but could be.

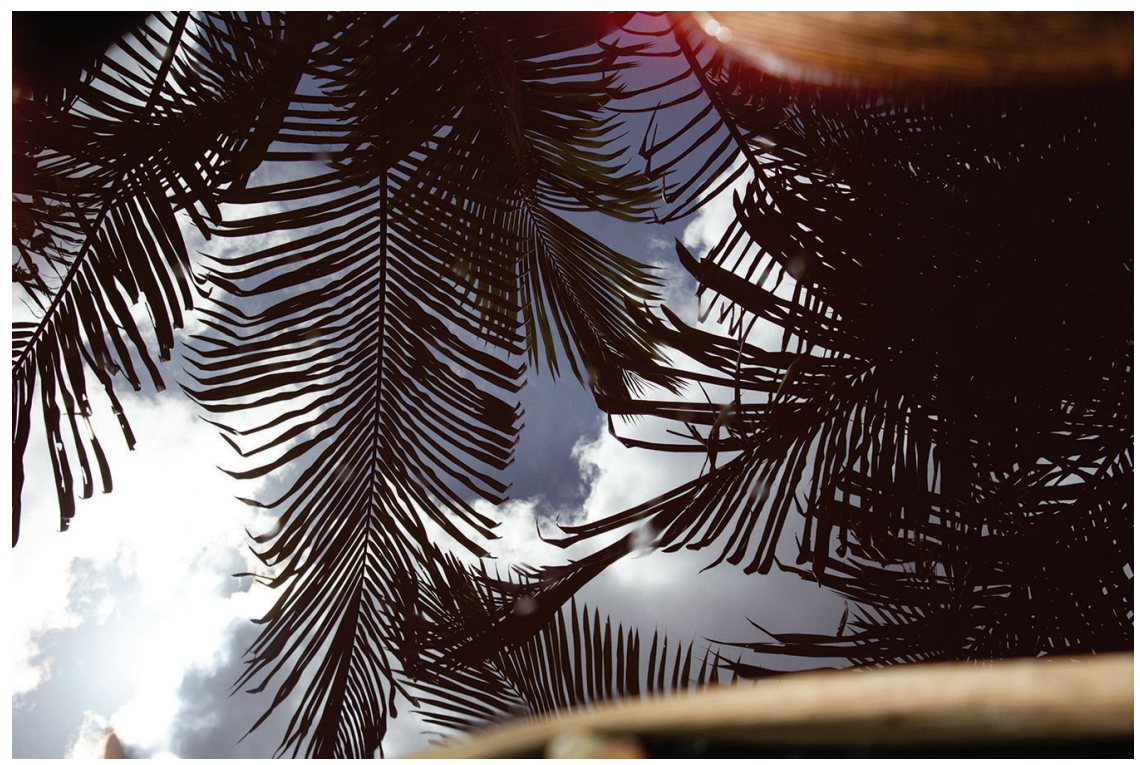

Figure 6. Sago fronds reflected in sago starch and water. Photo by Sophie Chao.

Multispecies ethnographers have drawn our attention to the ethical importance of practicing "multispecies love” (Tsing 2011, 19) in an era of widespread ecological destruction. The violence of plants on persons in the Upper Bian suggests equal attention must be paid to unloving others who may or may not be human. To care about the unloving is not (only) to redeem them as necessarily (or possibly) lovable in reciprocal ways. It is also to accept and recognize their unlovingness and consequent unloveability as meaningful in its own right. Never a straightforward either/or, loving and unloving as forms of care move across and through diversely situated bodies and practices. It is these transformations in multispecies loves and loathings that shape the lifeworlds of peoples like Marind of Khalaoyam who are most deeply and directly mired in the morally fraught predicament of interspecies care. 


\section{ABSTRACT}

This article explores how indigenous Marind of West Papua conceptualize the radical socio-environmental transformations wrought by large-scale deforestation and oil palm expansion on their customary lands and forests. Within the ecology of the Marind lifeworld, oil palm constitutes a particular kind of person, endowed with particular agencies and affects. Its unwillingness to participate in symbiotic socialities with other species jeopardizes the well-being of the life forms populating a dynamic multispecies cosmology, including humans. Drawing from ontological theories and the multispecies approach, I show how people in a remote place engage with adverse environmental transformations enacted by an other-than-human actor. Assumptions of human exceptionalism come under question in the context of a vegetal being that is exceptional in its own particular and destructive ways. Arguing for greater attention to otherthan-human species that are unloving rather than unloved, I explore the epistemological frictions that arise from combining the anthropology of ontology with multispecies ethnography. I also attend to the implications of these theoretical positions in the real world of advocacy for those struggling in and against growing social and ecological precariousness. [multispecies ethnography; anthropology of ontology; West Papua; agribusiness; oil palm]

\section{NOTES}

Acknowledgments I thank the Marind communities of the Upper Bian for their hospitality and critical insight into the analysis set out in this article. I also thank the members of the Merauke Secretariat for Peace and Justice for their invaluable logistical and moral support throughout the research. The content of this article benefited from inputs from Jaap Timmer, Eve Vincent, and Eben Kirksey. I also thank Karin Bolender, Laura McLauchlan, Cymene Howe, and three anonymous reviewers for Cultural Anthropology. This research was supported by an Endeavour International Postgraduate Scholarship, a Wenner-Gren Dissertation Fieldwork Grant, and a Macquarie University Fieldwork Research Grant.

1. All names are pseudonyms.

2. Most Marind in Khalaoyam communicate in Bahasa Indonesia with each other and neighboring ethnic groups. In this article, I indicate whether non-English terms are Indonesian or Marind.

3. See Nimuendajú 1939, 90 and 1946, 60; Tuzin 1972, 234; Seeger 1981, 105; Kahn 1988, 44; Battaglia 1990, 49; and Gregor and Tuzin 2001, 8.

4. See Malinowski 1935, 52-55; C. Hugh-Jones 1979, 114-132, 200-217; S. Hugh-Jones 1979, 165-73; Descola 1997, 93-98; Heckler 2004, 243-48; and Dundon 2005.

5. While there is a vast anthropological literature on agriculture and plant domestication (e.g., Morgan 1877; Childe 1928; Smith 1995), only a few scholars have investigated the subjectivity and agency of the plants involved (e.g., Mendum 2009; van Dooren 2012; van der Veen 2014).

6. Here, see http://www.palmoilinvestigations.org/names-for-palm-oil.html.

7. The only exceptions to this rule are kava and pigs, which are cultivated and raised by Marind as ritual foods for large congregations and feasts, respectively (Verschueren 1970, 45).

8. Lymphogranuloma venereum is a sexually transmitted disease caused by the bacterium Chlamydia trachomatis.

9. Although rice was not discussed by my interlocutors because the crop is not grown in Khalaoyam and its surrounds, one might speculate that it, too, could be conceived as 
an unloving and nonreciprocal person. Both plants are grown as large-scale monocrops and cultivated by non-Papuan settlers. Marind associate rice with Indonesians, whom they refer to as "rice-eaters," as opposed to Papuans, who are "sago-eaters." Like oil palm, rice is also promoted in state discourse as key to the economic and cultural development of West Papua.

10. The International Conference on Oil Palm and Environment (ICOPE) is one setting in which such research is presented.

\section{REFERENCES}

Ahmed, Sara

2010 The Promise of Happiness. Durham, N.C.: Duke University Press.

Anderson, David G.

2000 Identity and Ecology in Arctic Siberia: The Number One Reindeer Brigade. New York: Oxford University Press.

Archambault, Julie

2016 "Taking Love Seriously in Human-Plant Relations in Mozambique: Toward an Anthropology of Affective Encounters." Cultural Anthropology 31, no. 2: 244

Awas MIFEE 71. https://doi.org/10.14506/ca31.2.05

2012 "An Agribusiness Attack in West Papua: Unraveling the Merauke Integrated Food and Energy Estate." Report. https://awasmifee.potager.org/?page_id= 25.

Ballard, Chris

2002 “The Signature of Terror: Violence, Memory, and Landscape at Freeport." In Inscribed Landscapes: Marking and Making Place, edited by Bruno David and Meredith Wilson, 13-26. Honolulu: University of Hawai'i Press.

Barad, Karen

2012 “On Touching - The Inhuman that Therefore I Am.” differences 23, no. 3: 206223. https://doi.org/10.1215/10407391-1892943.

Barnes, Jessica

2016 "Separating the Wheat from the Chaff: The Social Worlds of Wheat." Environment and Society 7: 89-106. https://doi.org/10.3167/ares.2016.070106.

Battaglia, Debbora

1990 On the Bones of the Serpent: Person, Memory, and Mortality in Sabarl Island Society. Chicago: University of Chicago Press.

2017 “Aeroponic Gardens and Their Magic: Plants/Persons/Ethics in Suspension.” History and Anthropology 28, no. 3: 1-30. https://doi.org/10.1080/02757206. 2017.1289935.

Beldo, Les

2017 "Metabolic Labor: Broiler Chickens and the Exploitation of Vitality." Environmental Humanities 9, no. 1: 108-128. https://doi.org/10.1215/ 22011919-3829154.

Berrigan, Caitlin

2014 "Life Cycle of a Common Weed." In The Multispecies Salon, edited by Eben Kirksey, 164-80. Durham, N.C.: Duke University Press.

Bessire, Lucas, and David Bond

2014 “Ontological Anthropology and the Deferral of Critique." American Ethnologist 41, no. 3: 440-56. https://doi.org/10.1111/amet.12083.

Bird-David, Nurit

1992 “Beyond 'The Original Affluent Society': A Culturalist Reformulation.” Current Anthropology 33, no. 1: 25-47. https://doi.org/10.1086/204029.

Blanchette, Alex

2017 "Herding Species: Biosecurity, Posthuman Labor, and the American Industrial Pig." Cultural Anthropology 30, no. 3: 640-69. https://doi.org/10.14506/ ca30.4.09. 
Braidotti, Rosi

2006 Transpositions: On Nomadic Ethics. Malden, Mass.: Polity.

Callon, Michel

1986 "Some Elements of a Sociology of Translation: Domestication of the Scallops and the Fishermen of St Brieuc Bay." In Power, Action, and Belief: A New Sociology of Knowledge?, edited by John Law, 196-223. New York: Routledge.

Chamovitz, Daniel

2013 What a Plant Knows: A Field Guide to the Senses of Your Garden- and Beyond. New York: Scientific American Books.

Chao, Sophie

Forthcoming "Seed Care in the Palm Oil Sector." Environmental Humanities 10, no. 2: 421-46.

Childe, V. Gordon

1928 The Most Ancient East: The Oriental Prelude to European Prehistory. London: Kegan Paul.

Collard, Rosemary-Claire

2014 "Putting Animals Back Together, Taking Commodities Apart." Annals of the Association of American Geographers 104, no. 1: 151-65. https://doi.org/ 10.1080/00045608.2013.847750.

Crosby, Alfred W., Jr.

2003 The Columbian Exchange: Biological and Cultural Consequences of 1492. 30th anniversary edition. Westport, Conn.: Greenwood Publishing.

Cussins, Charis

1996 "Ontological Choreography: Agency through Objectification in Infertility Clinics." Social Studies of Science 26, no. 3: 575-610. https://doi.org/10.1177/ 030631296026003004.

Daly, Lewis, Katherine French, Theresa L. Miller, and Luíseach Nic Eoin

2016 “Botanical Ontologies." Special section, Journal of Ethnobiology 36, no. 1: 1-149.

Descola, Philippe

1997 The Spears of Twilight: Life and Death in the Amazon Jungle. Translated by Janet Lloyd. London: Flamingo.

Despret, Vinciane

2004 “The Body We Care For: Figures for Anthropo-Zoo-Genesis." Body and Society 10, no. 2: 111-34. https://doi.org/10.1177/1357034X04042938.

Dove, Michael R.

2011 The Banana Tree at the Gate: A History of Marginal Peoples and Global Markets in Borneo. New Haven, Conn.: Yale University Press.

Dundon, Alison

2005 "The Sense of Sago: Motherhood and Migration in Papua New Guinea and Australia." Journal of Intercultural Studies 26, nos. 1-2: 21-37. https://doi.org/ 10.1080/07256860500073997.

Ellen, Roy

2006 "Local Knowledge and Management of Sago Palm (Metroxylon Sagu Rottboell) Diversity in South Central Seram, Maluku, Eastern Indonesia." Journal of Ethnobiology 26, no. 2: 258-98. https://doi.org/10.2993/0278-0771(2006)26 [258:LKAMOS]2.0.CO;2.

Elmslie, Jim

2017 “The Great Divide: West Papuan Demographics Revisited; Settlers Dominate Coastal Regions but the Highlands Still Overwhelmingly Papuan.” Asia-Pacific

Eves, Richard Journal 15, no. 2. https://apjjf.org/2017/02/Elmslie.html.

1998 The Magical Body: Power, Fame, and Meaning in a Melanesian Society. Amsterdam: Harwood Academic.

Farhadian, Charles E.

2005 Christianity, Islam, and Nationalism in Indonesia. New York: Routledge. 
Fitzherbert, Emily B., Matthew J. Struebig, Alexandra Morel, Finn Danielsen, Carsten A.

Brühl, Paul F. Donald, and Ben Phalan

2008 "How Will Oil Palm Expansion Affect Biodiversity?" Trends in Ecology and Evolution 23, no. 10: 539-45. https://doi.org/10.1016/j.tree.2008.06.012.

Fox, James J.

1977 Harvest of the Palm: Ecological Change in Eastern Indonesia. Cambridge, Mass.:

Graeber, David Harvard University Press.

2015 "Radical Alterity is Just Another Way of Saying 'Reality': A Reply to Eduardo Viveiros de Castro." HAU 5, no. 2: 1-41. https://doi.org/10.14318/hau5. 2.003.

Gregor, Thomas A., and Donald Tuzin, eds.

2001 Gender in Amazonia and Melanesia: An Exploration of the Comparative Method. Berkeley: University of California Press.

Groube, Les

1989 "The Taming of the Rain Forests: A Model for Late Pleistocene Forest Exploitation in New Guinea." In Foraging and Farming: The Evolution of Plant Exploitation, edited by David R. Harris and Gordon C. Hillman, 292-304. London: Allen and Unwin.

Hall, Matthew

2011 Plants as Persons: A Philosophical Botany. Albany: State University of New York.

Haraway, Donna J.

1988 "Situated Knowledges: The Science Question in Feminism and the Privilege of Partial Perspective.” Feminist Studies 14, no. 3: 575-99. https://doi.org/ $10.2307 / 3178066$.

1997 Modest_Witness@Second_Millennium.FemaleMan ${ }^{\mathbb{C}} \_$Meets_OncoMouse ${ }^{T M}$ :Feminism and Technoscience. New York: Routledge.

2003 The Companion Species Manifesto: Dogs, People, and Significant Otherness. Chicago: Prickly Paradigm Press.

2007 "Speculative Fabulations for Technoculture's Generations: Taking Care of Unexpected Country." Australian Humanities Review 50: 95-118. http://doi.org/ 10.22459/AHR. 50.2011.06.

2008 When Species Meet. Minneapolis: University of Minnesota Press.

2016 Staying with the Trouble: Making Kin in the Chthulucene. Durham, N.C.: Duke University Press.

Hartigan, John, Jr.

2014 Aesop's Anthropology: A Multispecies Approach. Minneapolis: University of Minnesota Press.

2017 Care of the Species: Races of Corn and the Science of Plant Biodiversity. Minneapolis: University of Minnesota Press.

Hayward, Eva

2010 "Fingeryeyes: Impressions of Cup Corals." Cultural Anthropology 25, no. 4: 57799. https://doi.org/10.1111/j.1548-1360.2010.01070.x.

Heckler, Serena L.

2004 "Tedium and Creativity: The Valorization of Manioc Cultivation and Piaroa Women." Journal of the Royal Anthropological Institute 10, no. 2: 241-59. https:// doi.org/10.1111/j.1467-9655.2004.00188.x.

Hernawan, Budi J., and Theo P. A. van den Broek

1999 “Dialog nasional Papua: Sebuah kisah 'memoria passionis'.” Tifa Irian, week 3, March: 8.

Hugh-Jones, Christine

1979 From the Milk River: Spatial and Temporal Processes in Northwest Amazonia. New York: Cambridge University Press. 
Hugh-Jones, Stephen

1979 The Palm and the Pleiades: Initiation and Cosmology in Northwest Amazonia. New York: Cambridge University Press.

Hustak, Carla, and Natasha Myers

2012 "Involutionary Momentum: Affective Ecologies and the Sciences of Plant/Insect Encounters." differences 23, no. 3: 74-118. https://doi.org/10.1215/ 10407391-1892907.

Jacka, Jerry K.

2015 Alchemy in the Rainforest: Politics, Ecology, and Resilience in a New Guinea Mining Area. Durham, N.C.: Duke University Press.

Kahn, Miriam

1986 Always Hungry, Never Greedy: Food and the Expression of Gender in a Melanesian Society. New York: Cambridge University Press.

1988 “'Men Are Taro' (They Cannot Be Rice): Political Aspects of Food Choices in Wamira, Papua New Guinea.” Food and Foodways 3, nos. 1-2: 41-57. https://

Kirksey, Eben doi.org/10.1080/07409710.1988.9961936.

2012 Freedom in Entangled Worlds: West Papua and the Architecture of Global Power. Durham, N.C.: Duke University Press.

2015 Emergent Ecologies. Durham, N.C.: Duke University Press.

2017 "Lively Multispecies Communities, Deadly Racial Assemblages, and the Promise of Justice." South Atlantic Quarterly 116, no. 1: 195-206. https://doi.org/ 10.1215/00382876-3749614.

Kirksey, S. Eben, and Stefan Helmreich

2010 “The Emergence of Multispecies Ethnography." Cultural Anthropology 25, no. 4: 545-76. https://doi.org/10.1111/j.1548-1360.2010.01069.x.

Kohn, Eduardo

2013 How Forests Think: Toward an Anthropology Beyond the Human. Berkeley: University of California Press.

Leach, James

2003 Creative Land: Place and Procreation on the Rai Coast of Papua New Guinea. New York: Berghahn.

Li, Tanya Murray

2014 Land's End: Capitalist Relations on an Indigenous Frontier. Durham, N.C.: Duke University Press.

Lien, Marianne Elisabeth

2015 Becoming Salmon: Aquaculture and the Domestication of a Fish. Oakland, Calif.: University of California Press.

Malinowski, Bronislaw

1935 Coral Gardens and Their Magic: A Study of the Methods of Tilling the Soil and of Agricultural Rites in the Trobriand Islands. London: Allen and Unwin.

Marder, Michael

2013 Plant-Thinking: A Philosophy of Vegetal Life. New York: Columbia University Press.

2014 Pyropolitics: When the World is Ablaze. Lanham, Md.: Rowman and Littlefield.

2016 Grafts: Writings on Plants. New York: Univocal Publishing.

Margulis, Lynn, and Dorion Sagan

2000 What Is Life? Berkeley: University of California Press.

Marr, Carolyn

2011 "Twenty-Two Years of Top-Down Resource Exploitation in Papua." Down to Earth 89-90. http://www.downtoearth-indonesia.org/story/twenty-twoMcCarthy, John F. years-top-down-resource-exploitation-papua.

2010 "Processes of Inclusion and Adverse Incorporation: Oil Palm and Agrarian Change in Sumatra, Indonesia.” Journal of Peasant Studies 37, no. 4: 821-50. https://doi.org/10.1080/03066150.2010.512460. 
Meijaard, Erik, and Sheil Douglas

2013 "Oil Palm Plantations in the Context of Biodiversity Conservation." In Encyclopedia of Biodiversity, 2nd edition, edited by Simon A. Levin, 600-612. Waltham, Mass.: Academic Press.

Mendum, Ruth M.

2009 "Subjectivity and Plant Domestication: Decoding the Agency of Vegetable Food Crops." Subjectivity 28, no. 1: 316-33. https://doi.org/10.1057/sub.2009.15.

Monbiot, George

1989 Poisoned Arrows: An Investigative Journey through Indonesia. London: Michael Joseph. Morgan, Lewis $\mathrm{H}$.

1877 Ancient Society, or, Researches in the Lines of Human Progress from Savagery through Barbarism to Civilization. New York: Henry Holt.

Myers, Natasha

2015 “Conversations on Plant Sensing: Notes from the Field.” NatureCulture 3: 3566. http://natureculture.sakura.ne.jp/03-acting-with-non-human-entities.

Nimuendajú, Curt

1939 The Apinayé. Translated by Robert H. Lowie. Washington, DC: Catholic University of America Press.

1946 The Eastern Timbira. Translated by Robert H. Lowie. Berkeley: University of California Press.

Obidzinski, Krystof, Rubeta Andriani, Heru Komarudin, and Agus Andrianto

2012 "Environmental and Social Impacts of Oil Palm Plantations and Their Implications for Biofuel Production in Indonesia.” Ecology and Society 17, no. 1. https://doi.org/10.5751/ES-04775-170125.

Puig de la Bellacasa, Maria

2009 "Touching Technologies, Touching Visions: The Reclaiming of Sensorial Experience and the Politics of Speculative Thinking." Subjectivity 28, no. 1:297315. https://doi.org/10.1057/sub.2009.17.

Rose, Deborah Bird

2004 Reports from a Wild Country: Ethics of Decolonization. Sydney: University of New South Wales Press.

Rose, Deborah Bird, and Thom van Dooren, eds.

2011 "Unloved Others: Death of the Disregarded in the Time of Extinctions." Special issue, Australian Humanities Review. http://doi.org/10.22459/AHR.50.2011.

Rutherford, Danilyn

2003 Raiding the Land of the Foreigners: The Limits of the Nation on an Indonesian Frontier. Princeton, N.J.: Princeton University Press.

2012 Laughing at Leviathan: Sovereignty and Audience in West Papua. Chicago: University of Chicago Press.

Sahlins, Marshall

2011 "What Kinship Is (Part One)." Journal of the Royal Anthropological Institute 17, no. 1: 2-19. https://doi.org/10.1111/j.1467-9655.2010.01666.x.

Schneider, Katharina

2013 "Pigs, Fish, and Birds: Toward Multispecies Ethnography in Melanesia." Schrader, Astrid Environment and Society 4: 25-40. https://doi.org/10.3167/ares.2013.040103.

2012 "The Time of Slime: Anthropocentrism in Harmful Algal Research." Environmental Philosophy 9, no. 1: 71-93. https://doi.org/10.5840/envirophil 2012915.

Scott, James C.

1998 Seeing Like a State: How Certain Schemes to Improve the Human Condition Have Failed. New Haven, Conn.: Yale University Press. 
Scott, Michael W.

2013a "The Anthropology of Ontology (Religious Science?)." Journal of the Royal Anthropological Institute 19, no. 4: 859-872. https://doi.org/10.1111/14679655.12067.

2013b "Steps to a Methodological Nondualism." In “The Group for Debates in Anthropological Theory, The University of Manchester: The 2011 Annual Debate-Nondualism is Philosophy not Ethnography," edited by Soumhya Venkatesan, et al. Critique of Anthropology 33, no. 3: 300-360. https://doi.org/ 10.1177/0308275X13490310.

Seeger, Anthony

1981 Nature and Society in Central Brazil: The Suya Indians of Mato Grosso. Cambridge, Mass.: Harvard University Press.

Sheridan, Michael

2016 "Boundary Plants, The Social Production of Space, and Vegetative Agency in Agrarian Societies." Environment and Society 7: 29-49. https:// doi.org/10.3167/ ares.2016.070103.

Smith, Bruce D.

1995 The Emergence of Agriculture. New York: Scientific American Library.

Star, Susan Leigh, and James R. Griesemer

1989 'Institutional Ecology, 'Translations', and Boundary Objects: Amateurs and Professionals in Berkeley's Museum of Vertebrate Zoology, 1907-39.” Social Studies of Science 19, no. 3: 387-420. https://doi.org/10.1177/03063128 9019003001.

Stasch, Rupert

2009 Society of Others: Kinship and Mourning in a West Papuan Place. Berkeley: University of California Press.

Stengers, Isabelle

2010 Cosmopolitics, I. Translated by Robert Bononno. Minneapolis: University of Minnesota Press. Originally published in 1997.

Sunder Rajan, Kaushik, ed.

2012 Lively Capital: Biotechnologies, Ethics, and Governance in Global Markets. Durham, N.C.: Duke University Press.

Swadling, Pamela

1996 Plumes from Paradise: Trade Cycles in Outer Southeast Asia and Their Impact on New Guinea and Nearby Islands until 1920. Boroko and Queensland: Papua New Guinea National Museum/Robert Brown and Associates.

Tammisto, Tuomas

2018 "New Actors, Historic Landscapes: The Making of a Frontier Place in Papua New Guinea." PhD dissertation, University of Helsinki. http://urn.fi/URN: ISBN:ISBN\%20978-951-51-4027-2.

Timmer, Jaap

2007 “A Brief Social and Political History of Papua, 1962-2004." In The Ecology of Papua, Volume 6, edited by Andrew J. Marshall and Bruce M. Beehler, 10981123. Singapore: Periplus.

Trewavas, Anthony

2005 "Green Plants as Intelligent Organisms." Trends in Plant Science 10, no. 9: 41319. https://doi.org/10.1016/j.tplants.2005.07.005.

Tsing, Anna Lowenhaupt

1993 In the Realm of the Diamond Queen: Marginality in an Out-of-the-Way Place. Princeton, N.J.: Princeton University Press.

2005 Friction: An Ethnography of Global Connection. Princeton, N.J.: Princeton University Press.

2011 "Arts of Inclusion, or, How to Love a Mushroom." Australian Humanities Review 50: 5-21. http://doi.org/10.22459/AHR.50.2011.01. 
2015 The Mushroom at the End of the World: On the Possibility of Life in Capitalist Ruins. Princeton, N.J.: Princeton University Press.

Tuzin, Donald F.

1972 "Yam Symbolism in the Sepik: An Interpretative Account." Southwestern Journal of Anthropology 28, no. 3: 230-54. https://doi.org/10.1086/soutjanth.28.3. 3629221 .

van Baal, Jan

1966 Dema: Description and Analysis of Marind-Anim Culture (South New Guinea). The Hague: Martinus Nijhoff.

van der Veen, Marijke

2014 "The Materiality of Plants: Plant-People Entanglements." World Archaeology 46, no. 5: 799-812. https://doi.org/10.1080/00438243.2014.953710.

van Dooren, Thom

2012 "Wild Seed, Domesticated Seed: Companion Species and the Emergence of Agriculture.” PAN: Philosophy Activism Nature, no. 9: 22-28. https://search. Verschueren, Jan informit.com.au/documentSummary;dn=533917400637473;res=IELHSS.

1970 “Marind-Anim Land Tenure." New Guinea Research Bulletin, no. 38: 42-59. http://papuaweb.org/dlib/bk/ngb-38/_toc.html.

Viveiros de Castro, Eduardo

2011 "Zeno and the Art of Anthropology: Of Lies, Beliefs, Paradoxes, and Other Truths.” Common Knowledge 17, no. 1: 128-45. https://doi.org/10.1215/ 0961754X-2010-045.

von Uexküll, Jakob

1957 “A Stroll through the Worlds of Animals and Men." In Instinctive Behavior: The Development of a Modern Concept, translated and edited by Claire H. Schiller, 580. New York: International Universities Press. Originally published in 1934.

Wandersee, James H., and Elisabeth E. Schussler

2001 “Toward a Theory of Plant Blindness." Plant Science Bulletin 47, no. 1: 2-9. https: / /www.botany.org/bsa/psb/2001/psb47-1.html.

Weheliye, Alexander G.

2014 Habeas Viscus: Racializing Assemblages, Biopolitics, and Black Feminist Theories of the Human. Durham, N.C.: Duke University Press.

Wright, Kate

2014 “Becoming-With.” Environmental Humanities 5, no. 1: 277-81. https://doi.org/ 10.1215/22011919-3615514. 